\title{
Pollen morphology of the Megamexican cycads ReVeals the potential of MORPHOMETRICS TO IDENTIFY CYCAD GENERA
}

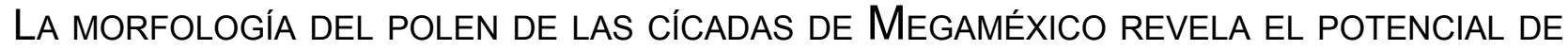 LA MORFOMETRÍA PARA IDENTIFICAR LOS GÉNEROS DE CÍCADAS}

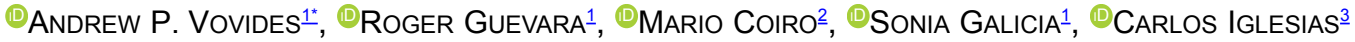 \\ ${ }^{1}$ Red de Biología Evolutiva, Instituto de Ecología, A.C., Xalapa, Veracruz, Mexico \\ ${ }^{2}$ Department of Biology, University of Fribourg, Fribourg, Switzerland. \\ 3ardín Botánico Fc. J. Clavijero, Xalapa,Veracruz, Mexico.
}

*Author for correspondence: andrew.vovides@inecol.mx

\begin{abstract}
Background: Although pollen morphology has always been an important tool in plant systematics, the possibility of distinguishing between related taxa is still debated. A difficult case is the cycads, where their morphology and small size is very similar. Pollen morphology has been important in plant systematics and determination at the species level is possible depending on the group. Controversial cases are the cycads, where their small pollen and smooth sculpture when observed under light microscopy present few useful characters for separation at the species level.

Question: Will cycad pollen morphometry be useful to distinguish taxa?

Study species: 15 species within the genera Ceratozamia, Dioon and Zamia were investigated with five species of each genus.

Methods: Pollen was obtained from both live specimens from the Clavijero Botanic Garden of the Instituto de Ecología, A.C., as well as herbarium specimens. Acetolyzed pollen was used for descriptions and morphometry, and non-acetolyzed pollen for MEB images.

Results: The thickness of the exine and pollen sculpture of Dioon differed from that of Ceratozamia and Zamia thus allowing its identification. The pollen morphology of Ceratozamia and Zamia is very similar and therefore difficult to distinguish between species.

Conclusions: The thicker exine of Dioon allows its pollen to be distinguished from the other two genera. Morphometric methods must be applied to distinguish pollen between species of Ceratozamia and Zamia.
\end{abstract}

Keywords: Cycadales, Mexico, pollen morphology, taxonomy, Zamiaceae.

\section{Resumen}

Antecedentes: Aunque la morfología del polen siempre ha sido una herramienta importante en la sistemática de las plantas, todavía se debate la posibilidad de distinguir entre taxa relacionados. Un caso difícil son las cícadas, donde su morfología y tamaño pequeño es muy parecido. La morfología del polen ha sido importante en la sistemática de las plantas y la determinación a nivel de especie es posible dependiendo del grupo. Casos discutibles son las cícadas, donde su polen pequeño y su escultura lisa cuando se observan bajo microscopía óptica presentan pocos caracteres útiles para la separación a nivel de especie..

Pregunta: ¿Será útil la morfometría del polen de las cícadas para distinguir taxa?

Especies de estudio: Se investigó 15 especies dentro los géneros Ceratozamia, Dioon y Zamia con cinco especies de cada género.

Métodos: Se obtuvo polen tanto especímenes vivas del Jardín Botánico Fco.J. Clavijero del Instituto de Ecología, A.C., así como especímenes de herbario. Se utilizó polen acetolizado para las descripciones y morfometría, y polen no acetolizado para imágenes SEM.

Resultados: El grosor de la exina y escultura del polen de Dioon diferió del polen de Ceratozamia y Zamia así permitiéndo su identificación. La morfología del polen de Ceratozamia y Zamia es muy similar y por lo tanto difícil de distinguir entre especies.

Conclusiones: La exina más gruesa de Dioon permite distinguir su polen de los otros dos géneros. Para distinguir el polen entre especies de los géneros Ceratozamia y Zamia es necesario aplicar métodos morfométricos.

Palabras clave: Cycadales, México, morfología de polen, taxonomía, Zamiaceae. 
The taxonomic value of pollen morphology for plant systematic studies is well established.

However, the phylogenetic gain at which dispersed pollen can be identified changes throughout seed plants. In Angiosperms, pollen can be often assigned to the genus or subgenus level (Coiro \& Barone-Lumaga 2013, Grimsson et al. 2018, Taylor et al. 2015). In the Gymnosperms, the absence of sculptural variation complicates identification, with varying degrees of usefulness of pollen traits within families (Bolinder et al. 2016). The following examples illustrate the possible range of taxonomic resolution. In the angiosperm genus Cuphea (Lythraceae) pollen morphologically is so distinct that dispersed pollen can be identified to several species of this genus (Graham 1999, Graham et al. 1985). Within the papillate Cupressaceae, taxa belonging to the short papilla group can be identified to genus level, Athrotaxus, Cunninhamia, and Taiwania respectively (Bouchal \& Denk 2020). The pollen morphology of the members of the two subfamilies belonging to the long papilla group show considerable overlaps in size, exine sculpture and other characteristics. Therefore, dispersed papillate Cupressaceae pollen of this type cannot unambiguously be assigned to a single genus.

Cycad pollen is small sulcate with few sculptural features, which can be easily confused in light microscopy (LM) investigation with pollen produced by Ginkgoales and other fossil taxa such as Cycadeoidales. Though pollen morphology and ultrastructure of some genera and species of the extant cycads have been studied using LM, scanning electron microscope (SEM), and transmission electron microscope (TEM) (Chamberlain 1912, Audran 1970a, $\underline{b}$, Audran \& Masure 1976, 1977, 1978, Dehgan \& Dehgan 1988). The degree of variation and the potential of pollen morphology to discriminate between different genera remain relatively unexplored and may hold additional information on evolutionary history and paleoecology. Burelo-Ramos et al. (2009) gives an example where pollen morphology can still provide additional characters to evaluate possible monophyletic groups within a complex of species, which might support some of the genera currently included in Pithecocteniinae (Bignoniaceae). RuízDomínguez et al. (2019) found seven pollen morphological attributes (five qualitative and two continuous) in the tribe Hylocereeae (Cactaceae) that exhibited useful variation. Brevicolpate pollen grains were shared by Kimnachia ramulosa and Pseudorhipsalis amazonica. Convex quadrangular outline in the polar view was shared by Weberocereus tunilla and Selenicereus glaber. The absence of spinules on the exine was shared by S. minutiflorus and $S$. stenopterus. The largest pollen grain, found in $S$. megalanthus, might be correlated with polyploidy. Meerow \& Dehgan (1985) found surface morphology of the pollen grain of Hymenocallis quitoensis is compared with other representative species of Hymenocallis and supports the inclusion of $H$. quitoensis within the genus.

Megamexico, a term coined by Rzedowski (1991) based on biotic affinities of Mexico with Central America as far as Nicaragua, represents one of the major diversity centres for cycads, particularly Zamiaceae. The Megamexican cycad flora includes the three genera Ceratozamia with 31 species, Dioon with 16 species and Zamia with 22 species, adding up to a total of 77 species (Calonje et al. 2019), Ceratozamia and Dioon are endemic to this region.

Here we describe the pollen of 15 Megamexican cycads (Table 1) using both LM and SEM, while testing for differences in morphology due to different preparation. We then test the power of morphometric analyses to discriminate between the pollen of different genera, and discuss the potential of this method to solve some of the unresolved issues surrounding cycad palynology.

Table 1. Taxa examined and reference specimens

\begin{tabular}{|c|c|c|}
\hline Taxa & Reference specimen & Herbarium \\
\hline Ceratozamia alvarezii & MAP-889 & MEXU \\
\hline Ceratozamia brevifrons & A. Vázquez B. 191 & XAL \\
\hline Ceratozamia decumbens & J. Rees 1690 & XAL \\
\hline Ceratozamia mexicana & AV-730 & XAL \\
\hline Ceratozamia euryphyllidia & MAP $s / n$ & XAL \\
\hline Dioon edule & J. Rees 1674 & XAL \\
\hline Dioon mejiae & AV-1554 & XAL \\
\hline Dioon merolae & AV-1240 & XAL \\
\hline Dioon spinulosum & AV-547 & XAL \\
\hline Dioon tomasellii & AV-1498 & XAL \\
\hline Zamia furfuracea & AV-037 & XAL \\
\hline Zamia katzeriana & AV-312 & XAL \\
\hline Zamia purpurea & AV-743 & XAL \\
\hline Zamia splendens & AV-1052 & XAL \\
\hline Zamia vazquezii & M.Vázq.Torres s/n & XALUV \\
\hline
\end{tabular}

\section{Materials and methods}

Pollen samples were taken from specimens deposited at XAL, MEXU, XALUV, and from living plants of the National Collection of Cycads held at the Fco. J. Clavijero Botanical Garden, of the Instituto de Ecología, A.C. In the case of samples taken from living plants a herbarium specimen was deposited at XAL (Table 1). The pollen sample of each species was divided into two treatments. In the first treatment, recently collected live pollen from the National Cycad Collection held in the Clavijero Botanic 
Garden, the grains were not acetolyzed but critical dried and observed and photographed using SEM. In the second treatment, the grains were acetolyzed, critical dried and then observed and measured under LM. The pollen processing for observations under SEM was modified from LudlowWiechers \& Ayala-Nieto (1983) where acetolysis was reduced to one minute to prevent collapse of the pollen grains giving them a boat-shaped appearance according to Marshall et al. (1986). The acetolyzed pollen grains were mounted according to Moore \& Webb (1978) for the reference collection. To contrast the hyaline property of the grains, differential interference techniques with Nomarski optics (DIC) were used at the LM level. For observations under LM and measurements the pollen grains were mounted in $20 \%$ glycerine and measured immediately. The measurements were made on 25 acetolyzed grains of pollen taken at random on the thickest portion of the exine. Ten non-acetolyzed grains were also measured since cycad pollen swells when placed in contact with aqueous solutions. For the reference preparations the grains were mounted in gelatine-glycerine. Photomicrographs were taken with a Zeiss Fomi III photomicroscope fitted with Plan-Neofluar and Plan-Apochromatic objectives and a digital camera. The terminology used is based on Halbritter et al. (2018). Exine measurements are expressed as range in $\mu \mathrm{m}$ with mean in brackets.

We used a discriminant analysis as well as a Random Forest (RF) method to test the potential of pollen traits to discriminate between either genera or species. In the RF two datasets, the first only including the four measurements from acetolyzed grains (Major axis, Polar axis, Polar view: Equatorial axis, Exine thickness; $n=10$ per species) and the second including a categorical trait indicating the presence of notable alveoli were used, for a total of four separate analyses (the two datasets used for both the genus-level classification and the species level classification). For each dataset, the data was separated into a training set (composed of $80 \%$ of the data) and a test set (containing $20 \%$ of the data), with 100 -fold cross-validation repeated 100 times. Random Forest classification was conducted using the function train in the package caret (Kuhn 2008).

\section{Results}

Acetolyzed pollen grain measurements of three dimensions, equatorial view, major axis, polar axis and polar view (equatorial axis) are given in Table 2. Nonacetolyzed pollen grain measurements of polar view, major equatorial axis, and minor equatorial axis are given in Table 3. The surface sculpturing under LM was observed to be psilate (smooth) in most cases and rugulate to granulaterugulate under SEM observation (Figures 1-3). The pollen grains when hydrated appear spherical (Figure 4) and when dehydrated they are boat shaped (Figure 5). Under LM the exine is observed to be barely tectate in Ceratozamia, with a tectum 0.8-2.5 $\mu \mathrm{m}$ thick, and Zamia, with a tectum 0.9$2.5 \mu \mathrm{m}$ thick. On the other hand, pollen grains of Dioon have a 1.4-3.5 $\mu \mathrm{m}$ thick tectum, probably linked with a generally thicker exine (Figure 6F-J). Discriminant analyses showing $95 \%$ confidence ellipsoids for the observation of 15 cycad species done for all species together and separately for those with thinner $(<1.85 \mu \mathrm{m})$ and thicker $(>1.85 \mu \mathrm{m})$ exine can be seen between Ceratozamia alvarezii, C. euryphyllidia, Dioon edule, D. mejiae and D. merolae (Figure 7).

Using a Random Forest method, the pollen grains can be identified to the correct genus with relatively good accuracy (0.93, $95 \%$ CI: $0.78-0.99$, Cohen's Kappa: 0.9) using the four measurements. Adding the presence or absence of visible alveoli does not improve the predictions (accuracy 0.9, 95 \% CI: 0.73-0.98, Cohen's Kappa: 0.85). On the other hand, identification at the species level is much less accurate either without $(0.6,95 \%$ CI: 0.4-0.77, Cohen's Kappa: 0.57$)$ or with the alveoli trait $(0.4,95 \%$ CI: 0.25-0.65, Cohen's Kappa: 0.39).

The genera Ceratozamoa, Dioon and Zamia as well as their species are described below:

Genus Ceratozamia Brongn. (Figure 1). Pollen grains of all species examined are shed as heteropolar, bilaterally symmetrical monads. Grains are sulcate, with the sulcus $3 / 4$ the length of the major equatorial axis. Exine is tectate. The sculpture is rugulate or granulate-rugulate, with the sulcus region being irregularly perforate. The dry, non-acetolyzed pollen grain is oblate elliptical with a slightly depressed sulcus region.

Perimeter in polar view is circular to sub-spheroidal when acetolyzed and mounted in $20 \%$ glycerine and irregularly oblate to collapsed (boat-shaped) when mounted in gelatine-glycerol or silicon oil.

Ceratozamia alvarezii Pérez-Farr. Vovides \& Iglesias (Figure 1A).- Pérez-Farrera et al. (1999).

Exine structure. 1.5 (2.0) $2.5 \mu \mathrm{m}$ thick. In optical section under DIC the exine appears tectate with barely visible alveoli. There is no clear distinction between sexine and nexine.

Sculpture. Under SEM, non-acetolyzed grains are rugulate ornamentation is homogenous. Under LM the exine surface of acetolyzed grains appears psilate.

Polar axis/equatorial axis ratio (P/E). 0.50(0.62)0.93 when acetolyzed, $0.84(0.90) 0.96$ when not acetolyzed. 


\section{Cycad pollen morphology}

Table 2. Acetolyzed pollen grain measurements and mounted in $20 \%$ glycerin $n=25$.

\begin{tabular}{|c|c|c|c|c|c|}
\hline Species & Equatorial view & Mean $\mu \mathrm{m}$ & Range & S.D. & $\%$ Coef. Var. \\
\hline \multirow[t]{3}{*}{ Ceratozamia alvarezii } & Major axis & 36.7 & $33.8-40.0$ & 2.0 & 5.5 \\
\hline & Polar axis & 22.7 & $17.5-35.0$ & 3.3 & 14.5 \\
\hline & Polar view: Equatorial axis & 36.4 & $32.5-40.0$ & 2.2 & 6.1 \\
\hline \multirow[t]{3}{*}{ C. brevifrons } & Major axis & 33.09 & $28.8-37.5$ & 2.21 & 6.68 \\
\hline & Polar axis & 18.85 & $12.5-25$ & 2.83 & 15 \\
\hline & Polar view: Equatorial axis & 34.22 & $30-40$ & 2.63 & 7.79 \\
\hline \multirow[t]{3}{*}{ C. decumbens } & Major axis & 35.5 & $31.3-40$ & 2.3 & 6.5 \\
\hline & Polar axis & 26.6 & $20-32.5$ & 4.2 & 15.8 \\
\hline & Polar view: Equatorial axis & 36.1 & $30-40$ & 2.6 & 7.2 \\
\hline \multirow[t]{3}{*}{ C. mexicana } & Major axis & 31.9 & $27.5-35.0$ & 2.03 & 6.36 \\
\hline & Polar axis & 33.3 & $15.0-20.0$ & 3.66 & 10.99 \\
\hline & Polar view: Equatorial axis & 31.7 & $27.5-35.0$ & 2.26 & 7.13 \\
\hline \multirow[t]{3}{*}{ C. euryphyllidia } & Major axis & 33.2 & $30.0-35.0$ & 1.4 & 4.1 \\
\hline & Polar axis & 23.2 . & $18.8-27.5$ & 2.5 & 11.0 \\
\hline & Polar view: Equatorial axis & 31.7 & $20-35$ & 2.9 & 9.0 \\
\hline \multirow[t]{3}{*}{ Dioon edule } & Major axis & 31.9 & $30-35$ & 1.32 & 4.1 \\
\hline & Polar axis & 19.5 & $16.3-22.5$ & 1.33 & 6.8 \\
\hline & Polar view: Equatorial axis & 31.3 & $30-32.5$ & 1.14 & 3.6 \\
\hline \multirow[t]{3}{*}{ D. mejiae } & Major axis & 35.4 & $31.3-40.6$ & 2.5 & 7.0 \\
\hline & Polar axis & 15.5 & $12.0-17.5$ & 1.6 & 10.5 \\
\hline & Polar view: Equatorial axis & 34.1 & $25.0-37.5$ & 2.8 & 8.1 \\
\hline \multirow[t]{3}{*}{ D. merolae } & Major axis & 32.3 & $30.0-36.3$ & 2.7 & 8.4 \\
\hline & Polar axis & 17.5 & $15.0-20.0$ & 1.8 & 10.5 \\
\hline & Polar view: Equatorial axis & 31.8 & $30.0-35.0$ & 1.5 & 4.7 \\
\hline \multirow[t]{3}{*}{ D. spinulosum } & Major axis & 29.6 & $25-35$ & 2.51 & 8.5 \\
\hline & Polar axis & 16.3 & $10-22.5$ & 2.44 & 8.6 \\
\hline & Polar view: Equatorial axis & 29.5 & $25-35$ & 2.55 & \\
\hline \multirow[t]{3}{*}{ D. tomasellii } & Major axis & 29.8 & $25.0-33.8$ & 2.5 & 8.5 \\
\hline & Polar axis & 15.8 & $12.5-17.5$ & 1.4 & 8.9 \\
\hline & Polar view: Equatorial axis & 28.5 & $25.0-33.8$ & 2.3 & 8.2 \\
\hline \multirow[t]{3}{*}{ Zamia furfuracea } & Major axis & 27.3 & $23.8-37.5$ & 2.9 & 10.8 \\
\hline & Polar axis & 14.7 & $10.0-17.5$ & 2.0 & 13.9 \\
\hline & Polar view: Equatorial axis & 27.9 & $25.0-37.5$ & 2.8 & 10.0 \\
\hline \multirow[t]{3}{*}{ Z. katzeriana } & Major axis & 29.3 & $27.5-32.5$ & 1.8 & 6.1 \\
\hline & Polar axis & 24.9 & $22.5-28.8$ & 2.1 & 8.4 \\
\hline & Polar view: Equatorial axis & 15.8 & $12.5-20.0$ & 1.7 & 10.5 \\
\hline \multirow[t]{3}{*}{ Z. purpurea } & Major axis & 27.2 & $25.0-28.8$ & 0.9 & 3.0 \\
\hline & Polar axis & 14.7 & $12.5-17.5$ & 1.7 & 11.7 \\
\hline & Polar view: Equatorial axis & 27.4 & $25.0-30.0$ & 2.0 & 7.2 \\
\hline \multirow[t]{3}{*}{ Z. splendens } & Major axis & 28.9 & $26.3-30.0$ & 1.5 & 5.2 \\
\hline & Polar axis & 16.7 & $15-20.0$ & 1.2 & 7.2 \\
\hline & Polar view: Equatorial axis & 29.1 & $27.5-30$ & 1.0 & 3.4 \\
\hline \multirow[t]{3}{*}{ Z. vazquezii } & Major axis & 30.2 & $27.0-35$ & 2.3 & 7.6 \\
\hline & Polar axis & 20.3 & $17.5-25$ & 2.2 & 10.8 \\
\hline & Polar view: Equatorial axis & 30.2 & $27.5-35$ & 2.6 & 8.6 \\
\hline
\end{tabular}


Vovides et al. / Botanical Sciences 99(1): 182-197. 2021

Table 3. Non-acetolyzed pollen grain measurements mounted in $20 \%$ glycerin $n=10$.

\begin{tabular}{|c|c|c|c|c|c|}
\hline Species & Polar view & Mean $\mu \mathrm{m}$ & Range & S.D. & $\%$ Coef. Var. \\
\hline \multirow[t]{2}{*}{ Ceratozamia alvarezii } & Major equatorial axis & 32.8 & $30.0-5.0$ & 1.9 & 5.9 \\
\hline & Minor equatorial axis & 29.2 & $27.5-30.5$ & 1.2 & 3.4 \\
\hline \multirow[t]{2}{*}{ C. brevifrons } & Major equatorial axis & 31.8 & $30-33.8$ & 0.99 & 3.1 \\
\hline & Minor equatorial axis & 22 & $20-22.5$ & 0.8 & 3.7 \\
\hline \multirow[t]{2}{*}{ C. decumbens } & Major equatorial axis & 30.1 & $20.8-32.5$ & 1.0 & 3.3 \\
\hline & Minor equatorial axis & 27.2 & $25-29.5$ & 1.5 & 5.5 \\
\hline \multirow[t]{2}{*}{ C. mexicana } & Major equatorial axis & 33.5 & $32.5-35.0$ & 1.03 & 3.07 \\
\hline & Minor equatorial axis & 22.1 & $19.5-23.8$ & 1.32 & 6.97 \\
\hline \multirow[t]{2}{*}{ C. euryphyllidia } & Major equatorial axis & 33.3 & $32.0-35.0$ & 1.2 & 3.5 \\
\hline & Minor equatorial axis & 23.1 & $22.0-24.5$ & 0.8 & 3.4 \\
\hline \multirow[t]{2}{*}{ Dioon edule } & Major equatorial axis & 23.9 & $21.6-26.2$ & 1.7 & 7.0 \\
\hline & Minor equatorial axis & 18.7 & $17.5-19.9$ & 1.0 & 5.2 \\
\hline \multirow[t]{2}{*}{ D. mejiae } & Major equatorial axis & 32.4 & $30.0-33.8$ & 1.5 & 4.7 \\
\hline & Minor equatorial axis & 24.9 & $23.8-26.3$ & 0.7 & 2.7 \\
\hline \multirow[t]{2}{*}{ D. merolae } & Major equatorial axis & 29.3 & $27.5-30.0$ & 1.0 & 3.4 \\
\hline & Minor equatorial axis & 25.7 & $23.8-27.5$ & 1.1 & 4.1 \\
\hline \multirow[t]{2}{*}{ D. spinulosum } & Major equatorial axis & 22.4 & 20.1-24.7 & 1.4 & 6.0 \\
\hline & Minor equatorial axis & 17.9 & $15.6-20.2$ & 1.1 & 6.3 \\
\hline \multirow[t]{2}{*}{ D. tomasellii } & Major equatorial axis & 25.5 & $22.5-27.5$ & 1.4 & 5.5 \\
\hline & Minor equatorial axis & 21.4 & $17.5-22.5$ & 1.5 & 7.1 \\
\hline \multirow[t]{2}{*}{ Zamia furfuracea } & Major equatorial axis & 26.8 & $25.0-27.5$ & 0.8 & 3.1 \\
\hline & Minor equatorial axis & 23.5 & $21.3-25.0$ & 1.4 & 6.0 \\
\hline \multirow[t]{2}{*}{ Z. katzeriana } & Major equatorial axis & 25.3 & $23.8-27.5$ & 0.9 & 3.7 \\
\hline & Minor equatorial axis & 22.1 & $20.0-23.8$ & 1.9 & 8.8 \\
\hline \multirow[t]{2}{*}{ Z. purpurea } & Major equatorial axis & 27.5 & $25.0-30.0$ & 1.5 & 5.4 \\
\hline & Minor equatorial axis & 19.7 & $18.8-21.3$ & 0.8 & 4.2 \\
\hline \multirow[t]{2}{*}{ Z. splendens } & Major equatorial axis & 26.0 & $23.3-29.5$ & 1.7 & 6.5 \\
\hline & Minor equatorial axis & 22.2 & $21.3-23.3$ & 0.6 & 2.7 \\
\hline \multirow[t]{2}{*}{ Z. vazquezii } & Major equatorial axis & 26.9 & $25-32.5$ & 2.3 & 8.6 \\
\hline & Minor equatorial axis & 22.4 & $18.8-25$ & 1.8 & 1.0 \\
\hline
\end{tabular}




\section{Cycad pollen morphology}
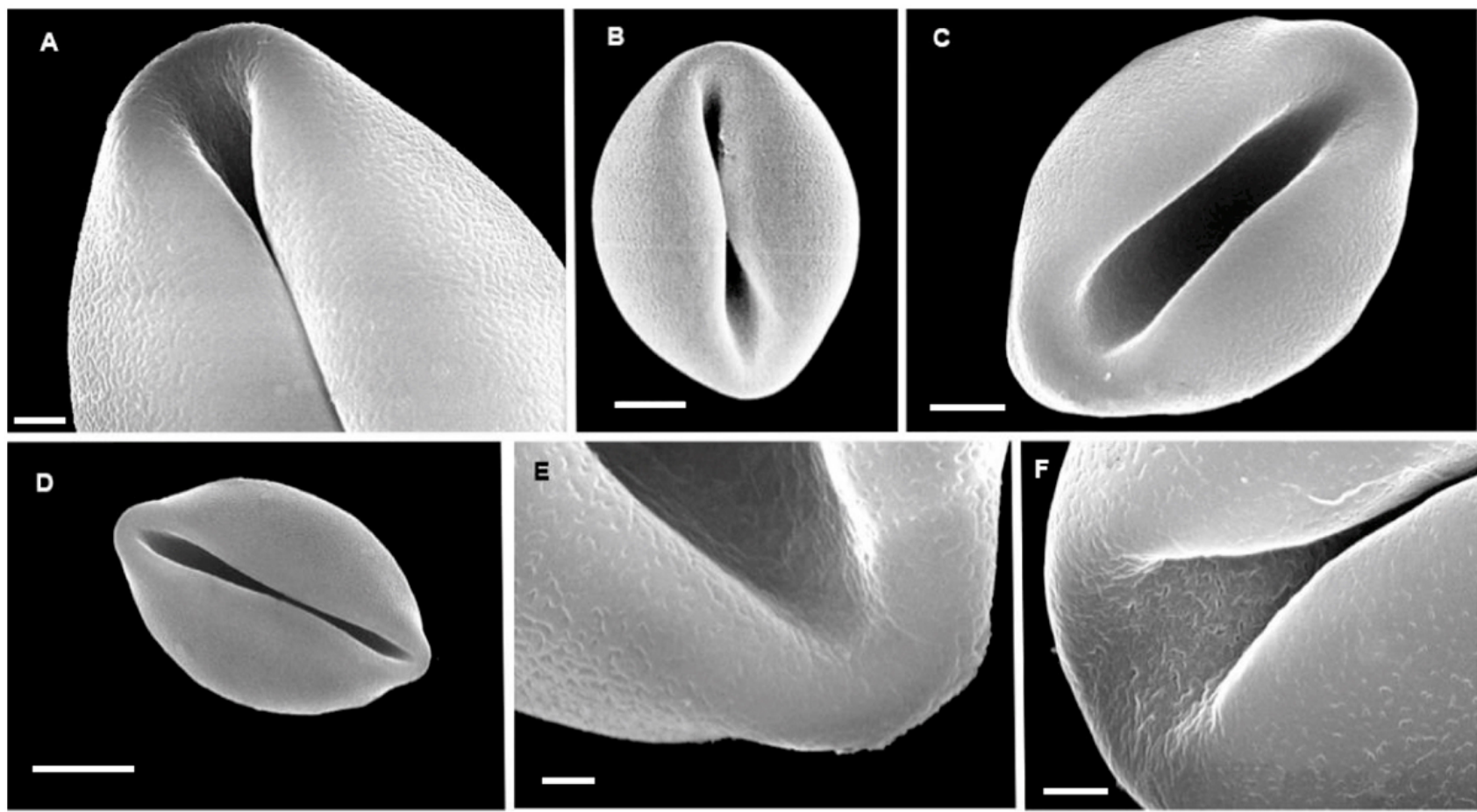

Figure 1. SEM images of non-acetolyzed pollen of Ceratozamia: A; Ceratozamia alvarezii. B; C. brevifrons. C; C. decumbens. D; C. euryphyllidia. E; C. euryphyllidia. F: C. mexicana. A, bar $=2 \mu \mathrm{m}$. B, C bars $=5 \mu \mathrm{m}$. D, bar $=10 \mu \mathrm{m}$. E, bar $=1 \mu \mathrm{m}$. F, bar $=2 \mu \mathrm{m}$. In E and $\mathrm{F}$ note perforate sulcus region.

Habit. Small plants with branching sub-globose stems becoming cylindrical with age, up to $50 \mathrm{~cm}$ long and $17.5 \mathrm{~cm}$ diameter. Leaves are up to 18 forming a terminal crown, up to $109 \mathrm{~cm}$ long and $61 \mathrm{~cm}$ wide, dark green. Leaflets up to 31 pairs, linear-lanceolate, plane up to $32.5 \mathrm{~cm}$ long, and $0.9 \mathrm{~cm}$ wide, dark green sharp tipped; petiole and rachis, armed with prickles. Female cones erect, cylindrical to barrel shaped, ochre, when mature up to $19 \mathrm{~cm}$ long and $10.5 \mathrm{~cm}$ diameter; peduncle up to $6.5 \mathrm{~cm}$ long, differences in vegetative morphology and cones distinguishes $C$. alvarezii species from its congeners.

Habitat. Oak forests.

Elevation. $950 \mathrm{~m}$.

Phenology. Cones appear from June to October.

Distribution. México; Endemic to Chiapas.

Reference specimen. M.A. Farrera 889 (MEXU).

Ceratozamia brevifrons Miq. (Figure 1B).- Vovides et al. (2012).

Exine structure. 1(1.6)2 $\mu \mathrm{m}$ thick. In optical section under DIC the exine is observed to be tectate with barely visible alveoli, there is no definition between sexine and nexine.

Sculpture. Under SEM the exine surface of non-acetolyzed is observed to be lightly rugulate and homogenous with the exception of the sulcus region that is observed to be irregularly perforate. Under LM the exine surface of acetolyzed grains appears psilate.

Polar/equatorial axis ratio $(\mathrm{P} / \mathrm{E})$. $0.33(0.57) 0.77$ when acetolyzed, 0.64(0.69)0.72 when not acetolyzed.

Habit. Short plants with erect to decumbent stems, up to $50 \mathrm{~cm}$ long, and $19 \mathrm{~cm}$ in diameter, bearing short leaves, 3-17, erect, keeled, up to $120 \mathrm{~cm}$ long, and $69 \mathrm{~cm}$ wide with spear-shaped, pointed leaflets, reaching $34.5 \mathrm{~cm}$ long, and $3.7 \mathrm{~cm}$ wide. This species is distinguished from its congeners by having short leaflets and keeled leaves.

Habitat. Transition between cloud forest and oak forest, generally on steep or rocky slopes.

Elevation. 800-1,200 m.

Phenology. Cones appear from February to July.

Distribution. Mexico; Endemic to central Veracruz.

Reference specimen. A. Vázquez-Blanco 191 (XAL).

Ceratozamia decumbens Vovides, Avendaño, Pérez-Farr. \& Gonz.-Astorga (Figure 1C).- Vovides et al. (2008).

Exine structure. 2(2.2)2.5 $\mu \mathrm{m}$ in optical section under DIC the exine is observed to be tectate with barely visible alveoli there is no distinction between sexine and nexine. 

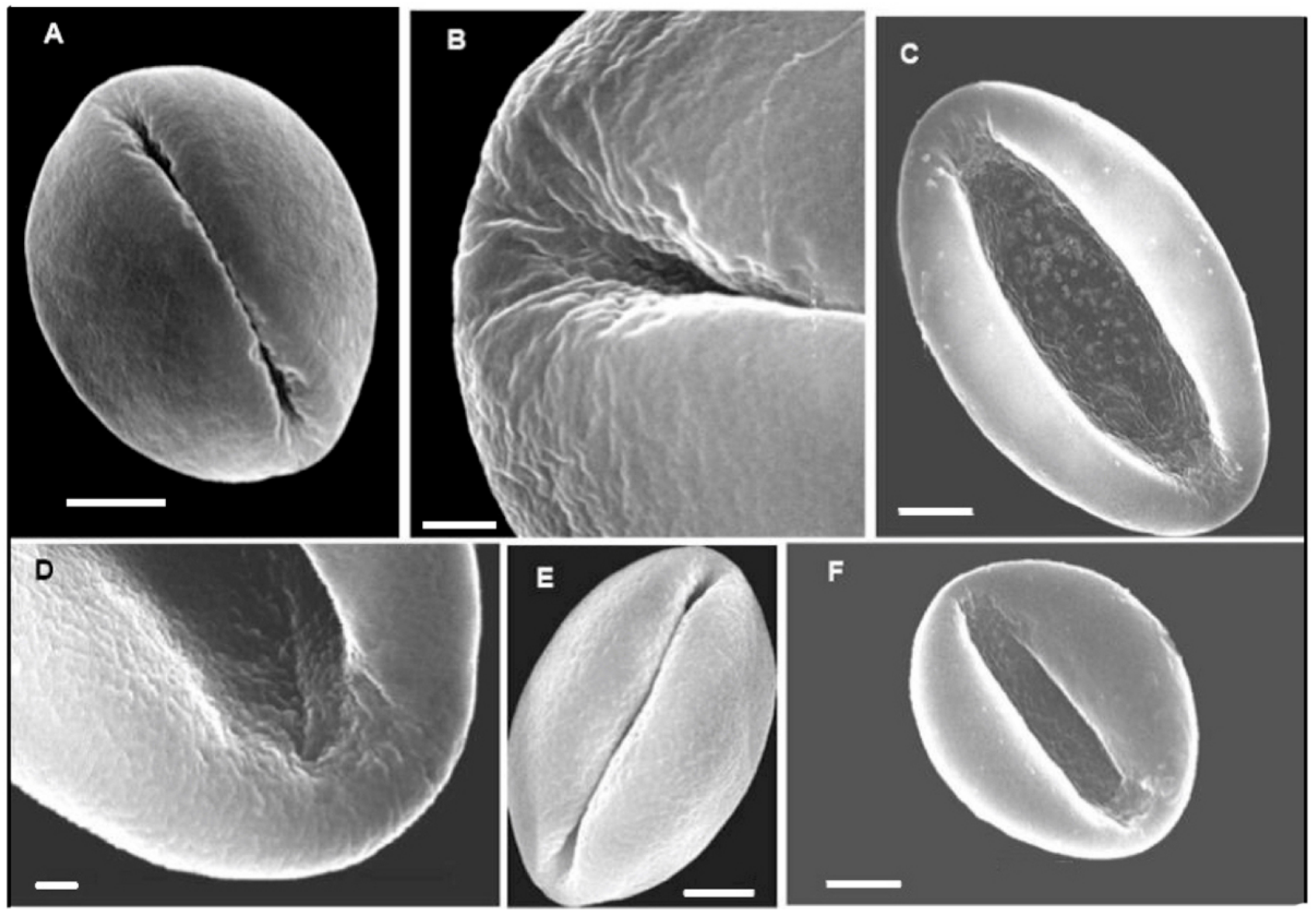

Figure 2. SEM images of non-acetolyzed pollen of Dioon: A; Dioon edule. B, C: D. mejiae. E; D. merolae. E; D. spinulosum. F; D. tomasellii. A, C, E, F bar $=5 \mu \mathrm{m} ; \mathrm{B}=2 \mu \mathrm{m}, \mathrm{D}=1 \mu \mathrm{m}$.

Sculpture. Under SEM the exine surface of non-acetolyzed grains appears to be rugulate. Exine ornamentation is homogenous with the exception of the sulcus region that is observed to be irregularly perforate. Under LM the exine surface of acetolyzed grains appears psilate.

Polar/equatorial axis ratio (P/E). - 0.5(0.75)0.89 when acetolyzed, 0.81(0.89)0.93 when not acetolyzed.

Habit. Plants with globose to cylindrical branched stems up to $20 \mathrm{~cm}$ long, growing on steep rocky substrates. Leaves usually decumbent on old plants, emerging reddish-brown, dark green or olive green when mature, up to $150 \mathrm{~cm}$ long, and $78 \mathrm{~cm}$ wide, leaflets 7-19 pairs, lanceolate plane, acuminate, up to $38 \mathrm{~cm}$ long and $4 \mathrm{~cm}$ wide. This species is easily distinguished from its congeners by its descending leaves and decumbent stems, leaflet articulations wide, reddish-brown female strobili with clear indument at the margins of the fertile scales.

Habitat. On Steep karstic slopes in sub-evergreen tropical forest.

Elevation. Approximately $700 \mathrm{~m}$.
Phenology. March to December.

Distribution. México; Endemic to central Veracruz.

Reference specimen. J. Rees 1690 (XAL).

Ceratozamia euryphyllidia Vázq.Torres, Sabato \& D.W.Stev. (Figure 1D-E).- Stevenson et al. (1986).

Exine structure. 1.0(1.4)2.0 $\mu \mathrm{m}$ thick in optical section under DIC the exine is observed to be tectate with barely visible columellae; there is no definition between sexine and nexine. The surface of acetolyzed grains appears slightly rugulate to psilate.

Ornamentation. Under SEM the exine surface of nonacetolyzed grains appears slightly rugulate. Ornamentation appears homogenous except in the sulcus region where in acetolyzed grains appears irregularly perforate.

Polar/equatorial axis ratio (P/E). 0.5(0.7)0.8 $\mu \mathrm{m}$ thick when acetolyzed, $0.65(0.7) 0.7 \mu \mathrm{m}$ when not acetolyzed. 


\section{Cycad pollen morphology}
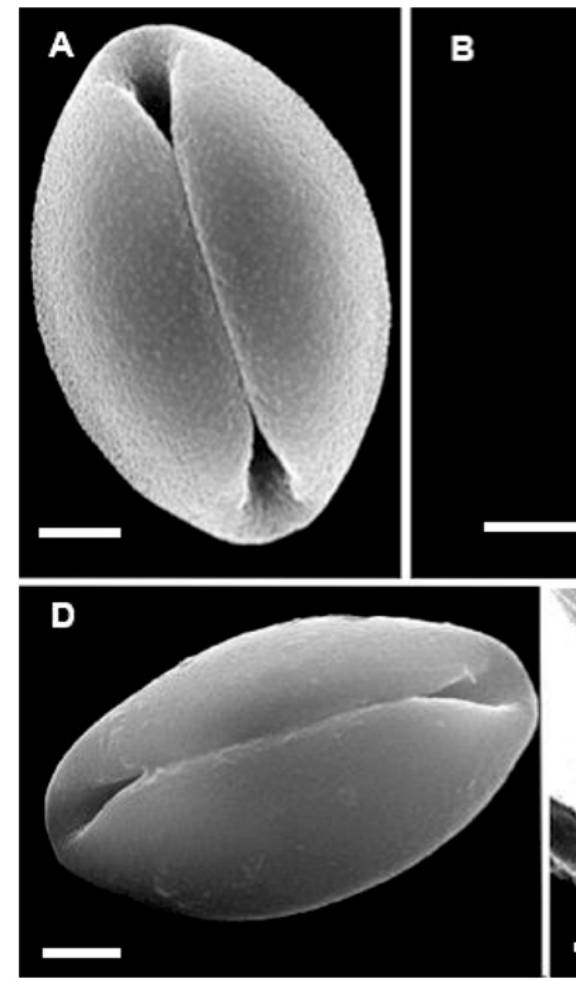

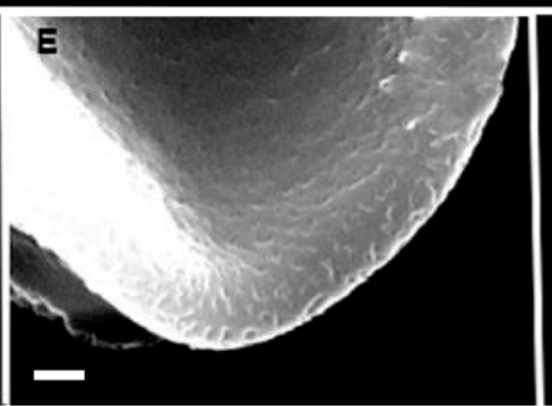

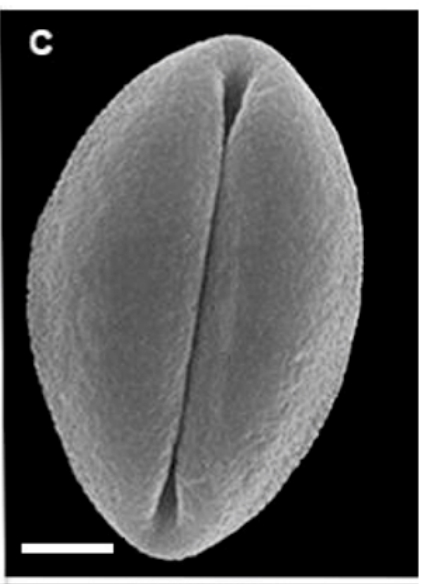

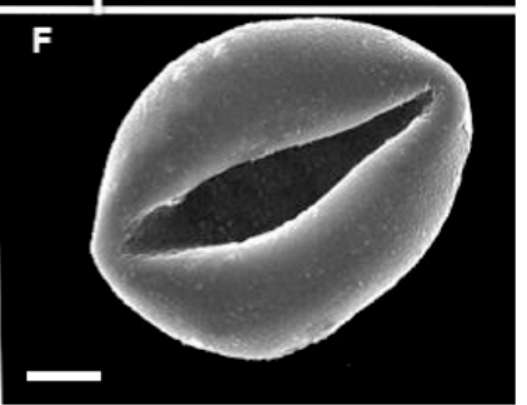

Figure 3. SEM images of non-acetolyzed pollen of Zamia: A. Zamia furfuracea B. Z. katzeriana. C. Z. purpurea. D. Z. splendens. E. Z. katzeriana. F. Z. vazquezii. A, B, C, D, F bars $=5 \mu \mathrm{m}$. E bar $=1 \mu \mathrm{m}$.

Habit. Short stemmed plants globose to cylindrical, leaves erect less than ten, 2-3.2 m long, leaflets subopposite to alternate, 12-26 pairs widely spaced, oblanceolate to widely obovate, inequilateral, $18-31 \mathrm{~cm}$ long, 9-16 cm wide, membranaceous to translucent, thin, $0.3-0.4 \mathrm{~mm}$ thick, sessile, attenuate at base (articulation $5-10 \mathrm{~mm}$ wide) and abruptly acuminate at the strongly asymmetric apex (2-4 cm long); male cone greenish-red when young, light gray when mature, usually solitary, long-cylindrical to elongateconical, $28 \mathrm{~cm}$ long, $3 \mathrm{~cm}$ diameter; female cone wine red when young, brown to dark brown when mature, usually solitary, cylindrical or slightly conical, $20 \mathrm{~cm}$ long including the peduncle, $5 \mathrm{~cm}$ in diam. (Stevenson 1986).

Habitat. Evergreen tropical rain forest on karstic topography.

Elevation. Approximately $300 \mathrm{~m}$.

Phenology. March to December.

Distribution. México; Endemic to southern Veracruz and northern Oaxaca.
Reference specimen. M.A. Pérez-Farrera s/n (XAL).

Ceratozamia mexicana Brongn. (Figure 1F).- Brongniart (1846).

Exine structure. $0.8(1.3) 1.8 \mu \mathrm{m}$ thick. In optical section under DIC the exine is observed to be tectate with barely visible columellae, there is no definition between sexine and nexine.

Sculpture. In SEM observation the exine surface of nonacetolyzed grains is granulo-rugulate. Ornamentation is homogenous with the exception of the sulcus region that is observed in acetolyzed grains to be irregularly perforate. In LM observation the exine surface of acetolyzed grains is rugulate to psilate.

Polar/equatorial axis ratio $(\mathrm{P} / \mathrm{E})$. $0.43(0.54) 0.67$ when acetolyzed, $0.59(0.66) 0.73$ when not acetolyzed. 

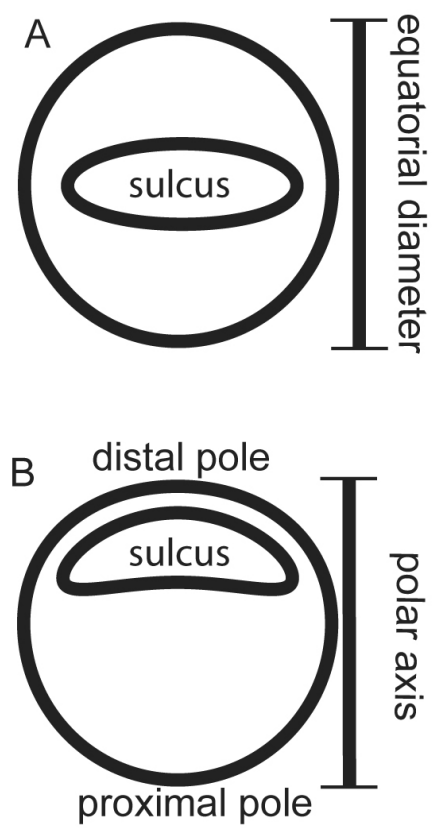

Figure 4. Schematic diagram of a hydrated pollen grain and orientation, after JM Bouchal

Habit. Robust plants with unbranched erect globose stems becoming cylindrical with age, up to one meter tall, or more and $35 \mathrm{~cm}$ in diameter in old specimens. Leaves up to 16 or more, arched forming a terminal crown, up to $300 \mathrm{~cm}$ long and $90 \mathrm{~cm}$ wide, dark green. Leaflets up to 50 pairs or more, oblong-lanceolate, sub-falcate, apex acuminate up to $45.5 \mathrm{~cm}$ long, and $3.4 \mathrm{~cm}$ wide; petiole and rachis armed with stout prickles. Female cones large, erect, olive-green, and leaning when mature, up to $47 \mathrm{~cm}$ long or more and $15 \mathrm{~cm}$ in diameter; peduncle up to $10 \mathrm{~cm}$ long. Male cones erect, cylindrical or narrowly conical up to $25 \mathrm{~cm}$ long or more and $4.5 \mathrm{~cm}$ in diameter. This species is distinguished from its congeners by being relatively large with large female strobili (Vovides et al. 2016).

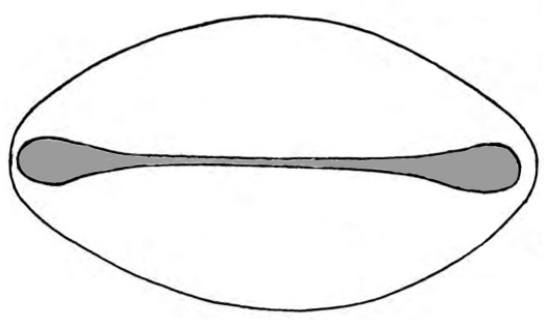

Figure 5. Schematic diagram of a collapsed pollen grain modified from Marshall et al. 1989.

Habitat. Sub deciduous tropical forest under tree shade generally on steep stony slopes.
Elevation. $800 \mathrm{~m}$.

Phenology. Cones appear from February to July.

Distribution. México; Central Veracruz and Puebla.

Reference specimen. A.P. Vovides 730 (XAL).

Genus Dioon Lindley (Figure 2).- Pollen from the species studied is shed as a monad. Grains are heteropolar, bilateral and sulcate. Exine is tectate, with well-defined alveoli that are notable in optical section. Sculpture is rugulate to psilate, with the sulcus region being irregularly perforate. Pollen grains are subspheroid with a depressed sulcus region when not acetolyzed and mounted in $20 \%$ glycerine, while appearing irregularly circular to oval or elliptic and collapsed when mounted in gelatine-glycerine or silicon oil.

Fourteen species of Dioon are known in Mexico with a range along the Gulf of Mexico seaboard from Nuevo León and Tamaulipas to Veracruz and northern Oaxaca. Along the Pacific seaboard the range is from Sonora to Chiapas with a concentration of species in Oaxaca. There is one species endemic to Honduras, D. mejiae.

Dioon edule Lindl. (Figure 2A).- Lindley (1843).

Exine structure. 2(2.6)4 $\mu \mathrm{m}$ thick. The exine is tectate clearly visible alveoli, but no clear differentiation between sexine and nexine.

Sculpture. Non-acetolyzed pollen is slightly rugulate and homogenous and the sulcus irregularly perforated. Under LM the exine surface appears psilate.

Polar/equatorial axis ratio (P/E). 0.54(0.61)0.69 when acetolyzed, $0.67(0.85) 0.92$ when not acetolyzed.

Habit. Arborescent up to $6 \mathrm{~m}$ tall, branched in old specimens with a terminal crown of rigid pinnate leaves.

Habitat. Ecotone between deciduous tropical forest and oak forest, on steep rocky slopes, karstic topography and canyon walls.

Elevation. 500-1,500 m.

Phenology. February to October

Distribution. Mexico State, Guanajuato, Hidalgo, Nuevo León, Querétaro, San Luis Potosí,

Tamaulipas and Veracruz.

Reference specimen. J. Rees 1674 (XAL).

Dioon mejiae Standl. \& L.O. Wiliams (Figs 2BC).Standley \& Williams (1951).

Exine structure. 2.5(2.95)3.0 $\mu \mathrm{m}$ thick, tectate in optical section under DIC with clearly visible alveoli, but no clear differentiation between sexine and nexine. 


\section{Cycad pollen morphology}

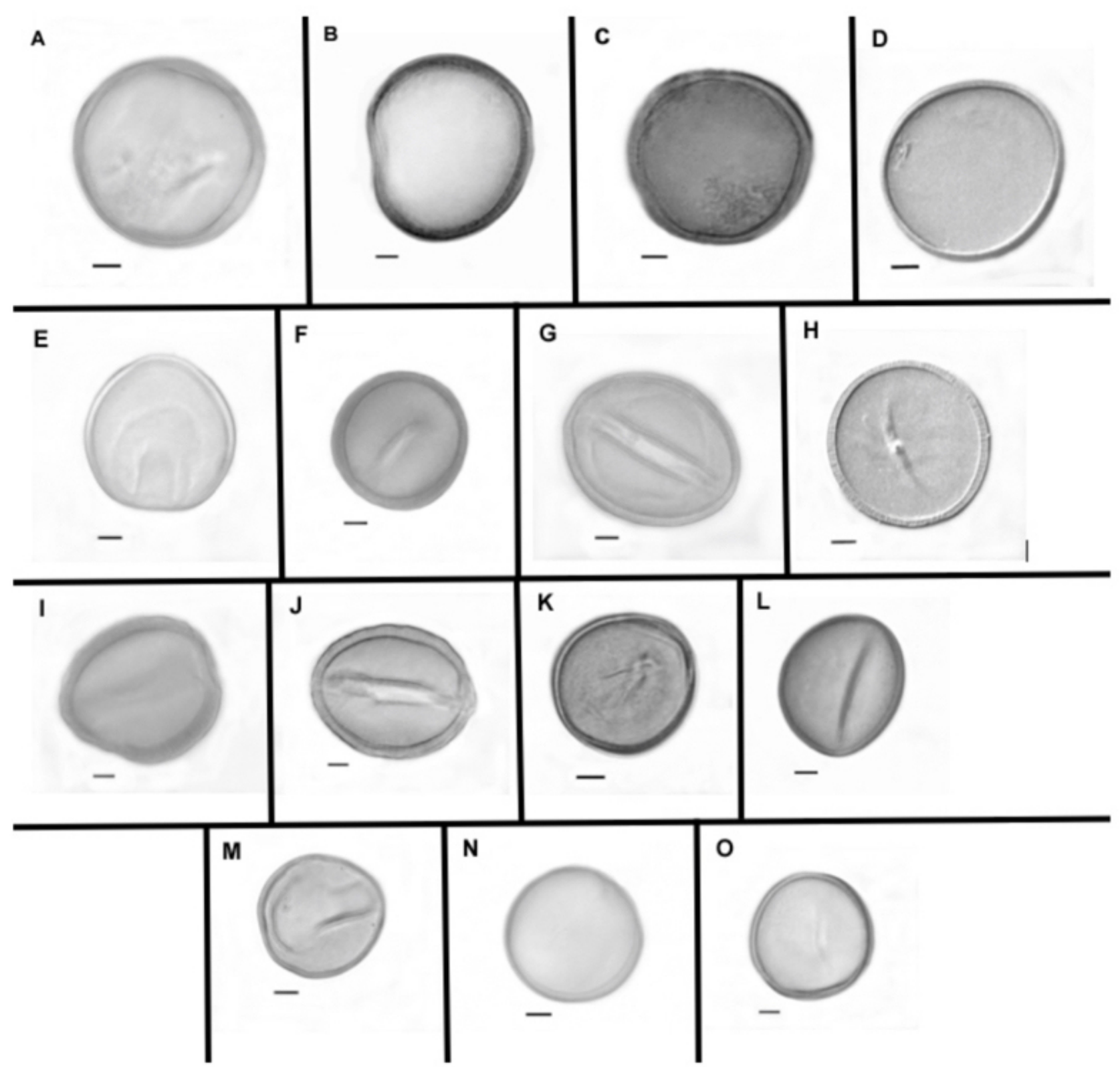

Figure 6. L.M. Images of acetolyzed pollen. A; Ceratozamia euryphyllidia. B; C. alvarezii. C; C. decumbens. D; C. brevifrons. E; C. mexicana. F; Dioon tomasellii. G; D. edule. H; D. spinulosum. I; D. merolae. J; D. mejiae. K; Zamia purpusii. L; Z. katzeriana M; Z. vazquezii. N; Z. furfuracea. O; Z. splendens. All bars $=5 \mu \mathrm{m}$.

Sculpture. Under SEM the exine surface is slightly rugulate to psilate when not acetolyzed, with sulcus region that being irregularly perforate. Under LM acetolyzed pollen the exine surface appears psilate.

Polar/equatorial axis ratio (P/E). 0.36(0.44)0.56 when acetolyzed, $0.70(0.77) 0.83$ when not acetolyzed.

Habit. Arborescent up to $10 \mathrm{~m}$ tall with a terminal crown of pinnate leaves up to $2 \mathrm{~m}$ long.
Habitat. Tropical forest in canyons and calcareous slopes in the Olancho region, Honduras.

Elevation. 50-300 m.

Phenology. August to March.

Distribution. Endemic to Honduras.

Reference specimen. A.P. Vovides 1554 (XAL).

Dioon merolae De Luca, Sabato \& Vázq.Torres (Figure 2D).- De Luca et al. (1981). 

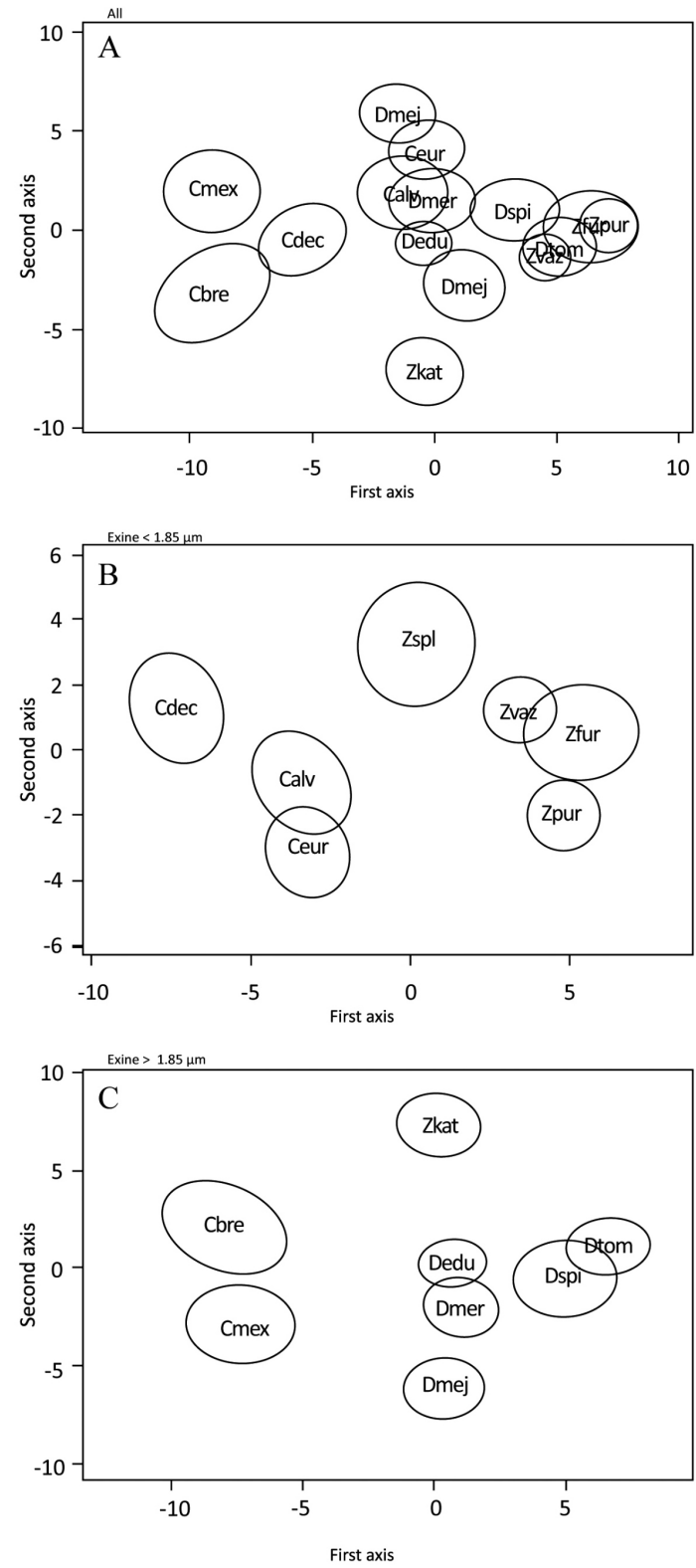

Figure 7. Discriminant analysis showing $95 \%$ confidence ellipsoids for the observation of 15 species of Megamexican cycads done for all species together and separately for those observation with thinner $(<1.85 \mu \mathrm{m})$ and thicker $(>1.85 \mu \mathrm{m})$ exine. A; All five species of the three genera together. B; species with exine thickness $<1.85 \mu \mathrm{m}$. C; species with exine thickness $>1.85 \mu \mathrm{m}$. Calv $=$ Ceratozamia alvarezii; Cbre $=C$. brevifrons; $\mathrm{Cdec}=C$. decumbens; $\mathrm{Cmex}=C$. mexicana; Ceur $=C$. euryphyllidia; Dedu = Dioon edule; Dmej = D. mejiae; Dmer $=D$. merolae; Dspi $=D$. spinulosum; Dtom $=D$. tomasellii; Zfur = Zamia furfuracea; Zkat $=Z$. katzeriana; Zpur $=Z$. purpurea; Zspl $=Z$. splendens; Z. vaz $=$ Z. vazquezii.
Exine structure. 2.0(2.8)3.5 $\mu \mathrm{m}$ thick, tectate in optical section under DIC with well-defined alveoli, but no clear differentiation between sexine and nexine.

Sculpture. Under SEM the exine surface of non-acetolyzed grains is rugulate. Ornamentation appears homogenous except in the sulcus region that appears reticulate.

Polar/equatorial axis ratio. (P/E) 0.39(0.54)0.69 when acetolyzed, $0.82(0.88) 0.96$ when not acetolyzed.

Habit. Arborescent reaching up to $6 \mathrm{~m}$ tall with pinnate leaves up to $1 \mathrm{~m}$ long forming and erect crown.

Habitat. Semi deciduous tropical forest, mostly on metamorphic rocks on hills and slopes.

Elevation. 50-300 m.

Phenology. August to March.

Distribution. Endemic to Southern Mexico in Chiapas and Oaxaca.

Reference specimen. A.P. Vovides 1240 (XAL).

\section{Dioon spinulosum Dyer (Figure 2E).- Dyer (1882-1886).}

Exine structure. 1.8(2.18)3 $\mu \mathrm{m}$ thick, tectate in optical section under DIC with well-defined alveoli but no definition between sexine and nexine.

Sculpture. Rugulate and homogenous except the sulcus that is irregularly perforate under SEM. Under LM the exine surface appears psilate.

Polar/equatorial axis ratio. (P/E) $0.4(0.55) 0.68$ when acetolyzed, $0.64(0.76) 0.87$ when not acetolyzed.

Habit. Arborescent, reaching $15 \mathrm{~m}$ tall with pinnate leaves up to $2 \mathrm{~m}$ long forming an apical crown.

Habitat. Semi deciduous tropical forest, on karst topography and calcareous slopes.

Elevation. 50-300 m.

Phenology. Form August to March.

Distribution. Northern Oaxaca and southern Veracruz.

Reference specimen. A.P. Vovides 547 (XAL).

Dioon tomasellii De Luca, Sabato \& Vázq. Torres (Figure 2F).- De Luca et al. (1984).

Exine structure. 2.0(2.5)3.0 $\mu \mathrm{m}$ thick, tectate in optical section under DIC with well-defined alveoli but no definition between sexine and nexine.

Sculpture. Under SEM the exine surface of non-acetolyzed pollen is slightly rugulate with an irregularly perforate sulcus. Under LM the exine surfaces appears psilate. 


\section{Cycad pollen morphology}

Polar/equatorial axis ratio (P/E). 0.44(0.56)0.88 when acetolyzed, $0.70(0.84) 0.95$ when not acetolyzed.

Habit. Short-stemmed plants up to $100 \mathrm{~cm}$ tall bearing pinnate leaves up to $2 \mathrm{~m}$ long with falcate leaflets forming an open crown.

Habitat. Oak and pine-oak forests on stony substrate.

Elevation. 600-1,800 m.

Phenology. February to September.

Distribution. Pacific seaboard from Sinaloa to Jalisco.

Reference specimen. A.P. Vovides 1498 (XAL).

Genus Zamia L. (Figure 3).- Pollen from the species studied is a heteropolar, bilateral, sulcate monad. Exine is tectate. The sulcus region covers three quarters or more the length of the major equatorial axis and is irregularly perforated. The exine surface is also observed to be rugulate under SEM and under LM rugulate to psilate. In optical section the alveoli are not well defined. Grains are sub-spheroidal with a depressed sulcus when not acetolyzed, and mounted in $20 \%$ glycerine, while being irregularly circular to oval or elliptic and collapsed when mounted in gelatine-glycerine or silicon oil. There are 81 known species in the genus that ranges from Florida and Georgia in the USA, Bahamas, Greater Antilles, Mexico, Central and South America.

\section{Zamia furfuracea L.f. (Figure 3A).- Linneus f. (1789).}

Exine structure. 0.9(1.1)1.4 $\mu \mathrm{m}$ thick, tectate in optical section under DIC with barely visible alveoli and no definition between sexine and nexine.

Sculpture. Non-acetolyzed grains, under SEM exine surface appears rugulate and homogenous with the exception of the sulcus region that appears slightly perforate and under LM the exine appears rugulate to psilate.

Polar/equatorial axis ratio. (P/E) 0.36(0.54)0.7 when acetolyzed, $0.8(0.88) 0.95$ when not acetolyzed.

Habit. Robust plants with generally subterranean stem 30 to $90 \mathrm{~cm}$ long, branching with age and becoming epigeous. Short pinnate leaves with imbricate oblanceolate to lanceolate, and heavily furfuraceous coriaceous leaflets with a light-brown orange indument.

Habiat. Stable coastal dunes and cliffs.

Elevation. Sea level to $50 \mathrm{~m}$.

Phenology. June to November.

Distribution. Endemic to Mexico along coastal southern Veracruz.

Reference specimen. A.P. Vovides 037 (XAL).
Zamia katzeriana (Regel) E.Rettig (Figure 3BE).- Rettig (1896).

Exine. 2.0(2.3)2.5 $\mu \mathrm{m}$ thick, tectate in optical section under DIC with barely visible alveoli and no clear definition between sexine and nexine.

Sculpture. Under SEM the exine surface non-acetolyzed pollen appears finely rugulate and homogenous with the exception of the sulcus zone that is irregularly perforate. Under LM the exine surface of acetolyzed pollen appears psilate.

Polar/equatorial axis ratio (P/E). 0.77(0.85)1.0 when acetolyzed, $0.8(0.88) 1.0$ when not acetolyzed.

Habit. Small plants up to $1 \mathrm{~m}$ tall with subterranean stem rarely branching bearing pinnate leaves from 40 to $100 \mathrm{~cm}$ long forming an erect to extended terminal crown with lanceolate dentate leaflets.

Habitat. Semi evergreen and deciduous tropical forests and derived secondary vegetation derived from these habitats.

Elevation. Sea level to $1,000 \mathrm{~m}$.

Phenology. May to December.

Distribution. Endemic to Mexico in southern Veracruz, Tabasco, Chiapas and Oaxaca.

Reference specimen. A.P. Vovides 312 (XAL).

Zamia purpurea Vovides, Rees \& Vázq.Torres (Figure 3C).Vovides et al. (1983).

Exine. 1.0(1.6)2.0 $\mu \mathrm{m}$ thick, tectate in optical section under DIC with barely visible alveoli with no clear definition between sexine and nexine.

Sculpture. Under SEM with non-acetolyzed pollen the exine surface appears rugulate and homogenous with the sulcus region irregularly perforate. Under LM the exine surface of acetolyzed pollen appears slightly rugulate.

Polar/equatorial axis ratio $(\mathrm{P} / \mathrm{E})$. $0.36(0.54) 0.66$ when acetolyzed, $0.65(0.74) 0.82$ when not acetolyzed.

Habit. Small plants up to $50 \mathrm{~cm}$ tall with non-branched subterranean stem bearing a terminal crown of pinnate leaves from 10 to $90 \mathrm{~cm}$ long with 3 to 4 pairs of elliptic, lanceolate to widely oblanceolate, dentate leaflets, sometimes but rarely 5 to 6 pairs of leaflets.

Habitat. Evergreen and semi evergreen tropical rain forests.

Elevation. 100 to $150 \mathrm{~m}$. 
Phenology. April to September.

Distribution. Rain forests of southern Veracruz and Oaxaca.

Reference specimen. A.P. Vovides 743 (XAL).

Zamia splendens Schutzman (Figure 3D).- $\underline{\text { Schutzman }}$ $\underline{(1984)}$.

Exine. 1.2(1.6)2 $\mu \mathrm{m}$ thick, tectate in optical section under DIC with barely visible alveoli and no clear definition between sexine and nexine.

Sculpture. Under SEM the exine surface in non-acetolyzed pollen appears rugulate, homogenous with the sulcus region irregularly perforate. Under LM the exine surface of acetolyzed grains appears psilate to slightly rugulate.

Polar/equatorial axis ratio. (P/E) 0.5(0.58)0.67 when acetolyzed, $0.76(0.86) 0.94$ when not acetolyzed.

Habit. Medium sized plant up to $70 \mathrm{~cm}$ tall with an unbranched subterranean stem up to $30 \mathrm{~cm}$ long bearing a terminal crown of pinnate leaves up to $70 \mathrm{~cm}$ long with 3 to 10 pairs of elliptic, oblong to oblanceolate leaflets that are serrulate to dentate in the apical portion.

Habitat.Evergreen and semi deciduous tropical rainforests.

Elevation. 100 to $800 \mathrm{~m}$.

Phenology. April to September.

Distribution. Endemic to Mexico in tropical rainforests of southern Veracruz, Tabasco and Chiapas.

Reference specimen. $A V-1052$ (XAL).

Zamia vazquezii D.W.Stev, Sabato \& De Luca (Figure 3E).Stevenson et al. (1995-96).

Exine structure. 1(1.5)2.0 $\mu \mathrm{m}$ thick, tectate in optical section under DIC and barely visible alveoli with no clear definition between the sexine and nexine.

Sculpture. Under SEM the exine surface in non-acetolyzed pollen appears rugulate, homogenous with the sulcus region irregularly perforate. Under LM the exine surface appears psilate to finely rugulate.

Polar/equatorial axis ratio $(\mathrm{P} / \mathrm{E})$. $0.55(0.67) 0.83$ when acetolyzed, $0.69(0.84) 0.92$ when not acetolyzed.

Habit. Small delicate fern-like plants with a subterranean stem bearing a terminal crown of pinnate leaves from 30 to $100 \mathrm{~cm}$ tall with papyraceous ovate to obpyriform dentate leaflets.
Habitat. Oak forests and semi-deciduous tropical rainforest.

Elevation. From 180 to $900 \mathrm{~m}$.

Phenology. April to December.

Distribution. Endemic to Veracruz.

Reference specimen. M. Vázquez Torres s/n (XALUV).

\section{Discussion}

Our investigation confirms some of the patterns previously reported for cycad pollen grains, with little differentiation in general pollen morphology (Chamberlain 1912, Audran 1970a, 므, Audran \& Masure 1976, 1977, 1978, Dehgan \& Dehgan 1988). The dry, non-acetolyzed grains are boat shaped, agreeing with previous reports (Audran \& Masure 1977). As soon as the grains come in contact with water (during the acetolysis and washing process) they swell until a spheroidal state is reached [see photomicrographs Figure 6 (LM) and compare with SEM images], sometimes to such a degree that the sulcus is hard to identify. When mounting in gelatine-glycerine or silicone oil most of the grains collapse or distort, thus making it difficult to take measurements. For this reason, measurements were taken in both their hydrated acetolyzed and non-acetolyzed states mounted in $20 \%$ glycerine, and the differences in measurements and pollen shape between acetolyzed and non-acetolyzed state are notable. Such changes in pollen dimensions according to the mounting medium and thickness of the microscopic preparations have been previously reported and discussed by Whitehead \& Langham (1965) and Whitehead \& Sheehan (1971).

The great similarity in morphology of the pollen grains within the Megamexican Zamiaceae is striking. Only the genus Dioon can be easily distinguished from Ceratozamia and Zamia by its considerable thicker exine. These differences seem to reflect the phylogenetic relationship between these genera, with Ceratozamia and Zamia being more closely related (sister) to each other than to Dioon (Salas-Leiva et al. 2013).

The morphometric analysis indicates that grains are rather uniform within genera, while differing between genera. This finding seems to validate the idea that cycad genera, while diverging deeper in time, underwent a more recent species-level diversification (Nagalingum et al. 2011).

Even though there is no major sculptural difference between the grains of the three genera investigated, especially when observed using LM, our morphometric analysis indicates that it could be possible to identify cycadalean pollen grains in the fossil record based on LM observation at least at genus level. The pollen grains of the Cycadales are usually hard to distinguish from the pollen grains of Ginkgoales and other fossil taxa, although some 
differences do exist in their ultrastructure (Tekleva et al. 2007). This makes it particularly hard to test hypotheses on the paleoecology and diversification of the cycads in deep time even though cycad pollen should be readily preserved in the fossil record (Frederiksen 1978) it is difficult for identification at species level. The high accuracy of our Random Forest classification based on acetolyzed grain measurements opens the possibility of using these methods to identify pollen grains produced by the extant cycad genera in the fossil record. A wider morphometric study of pollen grains across the Cycadales (living and fossil) with particular attention to pollen grain treatment might represent another avenue to improve our understanding of the pollen record of the cycads.

\section{Conclusions}

Pollen morphology alone is not useful for the delimitation of cycad species since the grains are extremely similar. At genus level Dioon pollen grains show a much thicker exine than that of Ceratozamia and Zamia however, polar axis, major axis and polar view dimensions were found to be of significance between these two genera. From a paleoecological point of view cycad pollen should be easily identified to genus level and it is hoped that the information provided here will be of use to cycad taxonomists and paleoecologists.

\section{Acknowledgements}

The authors thank the SEM technician Tiburcio Láez Aponte of INECOL for the production of the SEM images and to CONACyT for finance for various projects over the last 18 years. We thank JM Bouchal for critical review of the manuscript and for permission to use his illustration (Figure 5) showing orientation of a cycad pollen grain. We also thank Dalila Fragoso Tejas and Teresa Terrazas for their editorial orientation on the manuscript. We also wish to acknowledge Mario Vázquez Torres for the donation of Zamia vazquezii pollen used in this study.

\section{Literature cited}

Audran JC. 1970a. Structure de la paroi pollinique du Ceratozamia mexicana (Cycadacées) étudiées aux microscopes photonique et électronique après acétolyse ménagée. Comptes rendus de l'Académie des sciences 270: $1455-1457$.
Audran JC. 1970b. Sur l'ultrastructure de la paroi pollinique chez le Ceratozamia mexicana (Cycadacées). Pollen et Spores 12: 485-511.

Audran JC, Masure E. 1976. Precisions sur L' infrastructure de L' exine chez les cycadales prespermaphytes. Pollen et spores 18: 5-26.

Audran JC, Masure E. 1977. Contribution a la connaissance de la composition des sporodermes chez les Cycadales prespermaphytes etude en microscopie electronique a transmission M.E.T. et a balayage M.E.B. Palaeontographica 162: 115-158.

Audran JC, Masure E. 1978. La sculpture et l'infrastructure du sporoderme de Gingko biloba comparées a celles des enveloppes polliniques des Cycadales. Review of Palaeobotany and Palynology 26: 363-387.

Bolinder K, Norbäck Ivarsson L, Humphreys AM, IckertBond SM, Han F, Hoorn C, Rydin C. 2016. Pollen morphology of Ephedra (Gnetales) and its evolutionary implications. Grana 55: 24-51. DOI: https://doi.org/ $\underline{10.1080 / 00173134.2015 .1066424}$

Bouchal JM, Denk T. 2020. Low taxonomic resolution of papillate Cupressaceae pollen (former Taxodiaceae) impairs their applicability for palaeo-habitat reconstruction. Grana 59: 71-93. DOI: https://doi.org/ $\underline{10.1080 / 00173134.2019 .1701704}$

Brongniart AT. 1846. Note sur un nouveau genre de Cycadées du Mexique. Annales des Sciences Naturelles, Partie Botanique series 5: 5-9.

Burelo-Ramos CM, Lorea-Hernández FG, Vovides AP. 2009. Palynological survey of subtribe Pithecocteniinae (Bignonieae, Bignoniaceae). Botanical Journal of the Linnean Society 159: 155-162. DOI: https://doi.org/ 10.1111/j.1095-8339.2008.00897.x

Calonje M, Stevenson D, Osborne R. 2019. The World List of Cycads, online edition. http://www.cycadlist.org (accessed october 5, 2020).

Chamberlain CJ. 1912. Morphology of Ceratozamia. Botanical Gazette 53: 1-19.

Coiro M, Barone-Lumaga MR. 2013. Aperture evolution in Nymphaeaceae: insights from amicromorphological and ultrastructural investigation. Grana 52:192-201. DOI: https://doi.org/10.1080/00173134.2013.769626

Dehgan B, Dehgan NB. 1988. Comparative pollen morphology and taxonomic affinities in Cycadales. American Journal of Botany 75: 1501-1516. DOI: https://doi.org/10.1002/j.1537-2197.1988.tb11224.x

De Luca P, Sabato S., Vázquez Torres M. 1981. Dioon merolae (Zamiaceae), a new species from Mexico. 
Brittonia 33: 179-185. DOI: https://doi.org/10.2307/ $\underline{2806317}$

De Luca P, Sabato S, Vázquez Torres M.1984. Dioon tomasellii (Zamiaceae), a new species with two varieties from western Mexico. Brittonia 36: 223-227. DOI: https://doi.org/10.2307/2806511

Dyer WTT. 1882-1886. Cycadaceae. Biologia CentraliAmericana 3: 190-195. DOI: https://doi.org/10.5962/ bhl.title. 730

Frederiksen NO.1978. Preservation of Cycad and Ginkgo pollen. Review of Palaeobotany and Palynology 25: 163-179. DOI: https://doi.org/10.1016/0034-6667(78)90 $\underline{036-2}$

Graham A. 1999. Late Cretaceous and Cenozoic history of North American vegetation. New York, Oxford: Oxford University Press. ISBN-13: 978-0195113426

Graham A, Nowicke JW, Skvarla JJ, Graham SA, Patel V, Lee S. 1985. Palynology and systematics of the Lythraceae. I. Introduction and genera Adenaria through Ginoria. American Journal of Botany 72: 1012-1031. DOI: https://doi.org/10.1002/j.1537-2197.1985.tb0834 $\underline{6 . x}$

Grimsson F, Grimm GW, Zetter R. 2018. Evolution of pollen morphology in Loranthaceae. Grana 57: 16-116. DOI: https://doi.org/10.1080/00173134.2016.1261939

Halbritter H, Ulrich S, Grímsson F, Weber M, Zetter R, Hesse M, Buchner R, Svojtka M, Frosch-Radivo A. 2018. Illustrated pollen terminology. Heidelberg: Germany: Cham. Springer. ISBN 978-3-319-71365-6

Kuhn M. 2008. Building Predictive Models in R Using the caret Package. Journal of Statistical Software 28: 1-26. DOI: http://dx.doi.org/10.18637/jss.v028.i05

Lindley J. 1843. Dion edule. Edward's Botanical Register 29: $59-60$.

Linneus f. 1789. Zamia furfuracea. Hortus Kewensis (Aiton) 3: 477. DOI: https://doi.org/10.5962/bhl.titl e. 4504

Ludlow-Wiechers B, Ayala-Nieto ML.1983Catálogo palinológico para la Flora de Veracruz. No. 14. Familia Taxodiaceae. Biotica 8: 309-314.

Marshall J, Grobbelaar N, Coetzee J, Osborne R. 1989. Pollen morphology of the Cycadales with special reference to the Encepharlatos species. Pollen et Spores XXXI: 229-249.

Meerow A, Dehgan B. 1985. The auriculate pollen grain of Hymenocallis quitoensis Herb. (Amarillidaceae) and its systematic implications. American Journal of Botany 72: 540-547. DOI: https://doi.org/10.1002/j.1537-2197.19 85.tb08307.x

Moore PD, Webb JA.1978. An lllustrated Guide to Pollen Analysis. London: Hodder \& Stoughton. DOI: https:// doi.org/10.1007/BF02909461
Nagalingum NS, Marshall CR, Quental TB, Rai HS, Little DP, Mathews S. 2011. Recent synchronous radiation of a living fossil. Science 334: 796-799. DOI: https://doi.org/ $\underline{10.1126 / \text { science. } 1209926}$

Pérez-Farrera MA, Vovides AP, Iglesias C. 1999. A new species of Ceratozamia (Zamiaceae, Cycadales) from Chiapas, Mexico. Novon 9: 410-413. DOI: https:// doi.org/10.2307/3391741

Rettig E. 1896. Die cycadeen des botanischen gartens in Petersburg. Gartenflora 45: 148-149.

Ruíz-Domínguez C, Vovides AP, Sosa V. 2019. Systematic relevance of pollen morphology in tribe Hylocereeae (Cactaceae). Phytokeys 128: 121-140. DOI: https:// doi.org/10.3897/phytokeys.128.35842

Rzedowski J. 1991. Diversidad y orígenes de la flora fanerogamica de México. Acta Botánica Mexicana 14: 3-21. DOI: https://doi.org/10.21829/abm14.1991.611

Salas-Leiva DE, Meerow AW, Calonje M, Griffith MP, Francisco-Ortega J, Nakamura K, Stevenson DW, Lewis CE, Namoff S. 2013. Phylogeny of the cycads based on multiple single-copy nuclear genes: congruence of concatenated parsimony, likelihood and species tree inference methods. Annals of Botany, 112: 1263-1278. DOI: https://doi.org/10.1093/aob/mct192

Schutzman B. 1984. A new species of Zamia L. (Zamiaceae, Cycadales) from Chiapas, Mexico. Phytologia 55: 299-304.

Standley PC, Williams LO. 1951. Dioon mejiae. Ceiba 1: 36-38.

Stevenson DW. 1986. A new species of Ceratozamia from Veracruz, Mexico with comments on species relationships, habitats, and vegetative morphology in Ceratozamia. Brittonia 38: 17-26. DOI: https://doi.org/ $\underline{10.2307 / 2807413}$

Stevenson DW, Sabato S, Moretti A, De Luca P. 1995-96. What is Zamia fischeri Miquel? Delpinoa 37-38: 9-17.

Taylor ML, Cooper RL, Schneider EL, Osborn JM. 2015. Pollen structure and development in Nymphaeales: insights into character evolution in an ancient angiosperm lineage. American Journal of Botany 102: 1685-1702. DOI: https://doi.org/10.3732/ajb.1500249

Tekleva MV, Polevova SV, Zavialova NE. 2007. On some peculiarities of sporoderm structure in members of the Cycadales and Ginkgoales. Paleontological Journal 41: 1162-1178. DOI: https://doi.org/10.1134/S00310301 $\underline{07110159}$

Vovides AP, Rees JD, Vazquez Torres M. 1983. Zamiaceae. In: Gomez-Pompa, editor. Flora de Veracruz, Fasc. 26: 1-31 INIREB, Xalapa.

Vovides AP, Avendaño S, Pérez-Farrera MA, GonzálezAstorga J. 2008. A new species of Ceratozamia (Cycadales, Zamiaceae) from Veracruz, Mexico. Novon 18: $109-114$. DOI: https://doi.org/10.3417/2006063 


\section{Cycad pollen morphology}

Vovides AP, Avendaño S, Pérez-Farrera MA, Stevenson DW. 2012. What is Ceratozamia brevifrons (Zamiaceae)? Brittonia 64: 35-42. DOI: https://doi.org/ 10.1007/s12228-011-9199-8

Vovides AP, Stevenson DWm, Pérez-Farrera MA, LópezMendoza S, Avendaño S. 2016. What is Ceratozamia mexicana (Zamiaceae)? Botanical Sciences 94: 419-429. DOI: https://doi.org/10.17129/botsci.449

Associate editor: Monserrat Vázquez Sánchez

Author contributions: APV, writing, fieldwork, national cycad collection curation; RG, Statistical analyses, discriminants and Figure 7; MC, contribution to writing, Random Forest analysis; $\mathrm{SG}$, pollen processing, acetolysis, microscope slide preparation, photomicrography and slide collection; CI, early collection fieldwork, maintenance of the national cycad living collection at the botanic garden and photomicrography.
Whitehead DR, Langham EJ. 1965. Measurement as a means of identifying fossil maize pollen. Bulletin of the Torrey Botanical Club 92: 7-20. DOI: https://doi.org/ $\underline{10.2307 / 2483309}$

Whitehead DR, Sheenhan MC. 1971. Measurement as a means of identifying fossil maize pollen. II. The effect of the slide thickness. Bulletin of the Torrey Botanical Club 98: 268-271. DOI: https://doi.org/10.2307/2483626 